\title{
THE FORMULATION OF THE EUROPEAN PILLAR: WHICH EFFECTS ON THE SOCIAL RIGHTS?
}

\section{LA FORMULACIÓN DEL PILAR EUROPEO: ¿CUÁLES SON LOS EFECTOS SOBRE LOS DERECHOS SOCIALES?}

\section{CATERINA BUCCHERI}

Doctoral student of Migrants Studies

University of Grenade, Spain. 


\begin{abstract}
The guarantee of social rights and fundamental freedoms are today one of the main activities of the E.U. Only in the 1990s did the European Economic Community begin to transform itself into the European Union, extending the sphere of its activities from the economic to the political and social fields. the last phase was the proclamation of the European Pillar of Social Rights. The pillar is not legally binding, it does not automatically imply that the principles and rights contained in it are guaranteed, considering that the monetary policy of the Union and the breakdown of the different national policies divide Europe. To change this context, the federal structure of the European institution is necessary. This institution should have a political personality capable of aggregating and changing monetary policy, reviewing the rigidity of the Fiscal Compact, since to date it does not take into account the economic and social variables that Europe is experiencing. The next step is the introduction of a social and integration policy managed directly by the central entity, capable of uniting, introducing transnational solidarity, which would certainly encourage the growth of this inclusive political model.
\end{abstract}

KEYWORDS: European Union. Social rights. Social pillar. Realization. Political commitment.

\title{
RESUMEN
}

La garantía de los derechos sociales y las libertades fundamentales es hoy en día una de las principales actividades de la EE.UU. Sólo en la década de 1990 la Comunidad Económica Europea comenzó a transformarse en la Unión Europea, extendiendo el ámbito de sus actividades del campo económico al político y social y la última fase fue la proclamación del Pilar Europeo de los Derechos Sociales. El Pilar no es legalmente vinculante, no implica automáticamente que los principios y derechos que contiene estén garantizados, si se considera que la política monetaria de la Unión y la brecha entre las diferentes políticas nacionales dividen a Europa. Para cambiar este contexto, se necesita un desarrollo federalista de la institución europea. Esta institución debería tener una personalidad política capaz de agregar y cambiar la política monetaria, revisando la rigidez del Pacto Fiscal, ya que hasta hoy no tiene en cuenta las variables económicas y sociales que está experimentando Europa. El siguiente paso es la introducción de una política social y de integración administrada directamente por la entidad central, capaz de unir, introducir la solidaridad transnacional, lo que seguramente impulsaría el crecimiento de este modelo político inclusivo.

PALABRAS CLAVE: Unión Europea. Derechos Sociales. Pilar Social. Realización. Empeño Político.

This communication was presented at the Doctoral Seminar of Investigation "Pilar Europeo de derechos sociales, trabajo y migraciones: nuevos retos" held on 4 and 5 April 2018 as part of the Ph.D. Program in Migrant Studies of the University of Grenade.

e-Revista Internacional de la Protección Social, ISNN 2445-3269. 2018, Vol. III, No 1

http://dx.doi.org/10.12795/e-RIPS.2018.i02.13. Páginas: 230-244

Página 231 
SUMMARY

I. INTRODUCTION

II. SOCIAL RIGHTS: THE ARTICULATED PATH OF THE EUROPEAN UNION

III. INCIDENCE OF THE PILLAR IN THE SOCIAL POLICIES OF THE EUROPEAN UNION

IV. THE COMPLEXITY OF NATIONAL WELFARE SYSTEMS IN THE IMPLEMENTATION OF THE EUROPEAN PILLAR

V. CONCLUSIONS

e-Revista Internacional de la Protección Social, ISNN 2445-3269. 2018, Vol. III, N ${ }^{\mathrm{o}} 1$

http://dx.doi.org/10.12795/e-RIPS.2018.i02.13. Páginas: 230-244

Página 232 


\section{INTRODUCTION}

The "European social model" is based on a principle of a general nature since each member state adopts a specific prototype of social policies to meet the needs of its citizens, from which it derives that the protection of the same social rights takes place through different legislative forms. It must be considered that the implementation of the welfare state requires considerable costs for its application, therefore the standardization of social policies in Europe is an objective that is difficult to implement.

Compliance with the restrictive parameters of the European Monetary Policy has not allowed the removal of inequalities in the EU area, it would therefore be necessary to adopt a uniform social model for protections and guarantees in all the Member States.

With the proclamation of the European Pillar of Social Rights of 2015, the E.U. wanted to give member states a guide to improve the living conditions of citizens. From this document, however, nothing is highlighted as regards the projects related to immigration and integration processes, which were instead provided for by the Charter of Fundamental Rights of the EU of 2001.

This gap represents discrimination, given that the admission and integration strategies have been abandoned, the implementation of which is left to individual Member States, highlighting the political limits of the EU the consequence was a lack of guarantee of rights, which, even if enunciated with Community standards, were limited and cannot represent a reference for a desired general model to be applied in the Union.

Within the member countries, there are four different types of social status model, to be distinguished between those applied in the southern states, in the Anglo-Saxon countries, in the northern states and in the continental states, which will then be investigated further.

Only a political transformation in the federal sense of the E.U. it can really eliminate social inequalities with a policy of economic support for the exercise of social rights, by claiming the resources and distribution of the same in order to obtain an effective usability.

After the 2008 economic crisis, the Member States, especially those with greater national debt, have reduced the resources allocated to the welfare state, and since the economic matter is supranational, with the imposition of compliance with the monetary parameters, in the individual states the weaker groups, including foreign immigrants, have seen their social guarantees progressively diminished, demonstrating that the only monetary union is insufficient to face the social gap present in the E.U. area today In fact, in the individual Member States, the economic capacity of welfare is the only parameter that makes the enjoyment of social rights concrete and effective.

\section{SOCIAL RIGHTS: THE ARTICULATED PATH OF THE EUROPEAN UNION}

The protection of human rights and essential freedoms represent today one of the most important activities of the European Union that in this field is recent, since only in the

e-Revista Internacional de la Protección Social, ISNN 2445-3269. 2018, Vol. III, No 1

http://dx.doi.org/10.12795/e-RIPS.2018.i02.13. Páginas: 230-244

Página 233 
nineties the European Economic Community began to transform itself into the European Union, extending the sphere of its activities from the economic to the political-social field.

The European Treaties simply stated that the rights of persons had to be taken into account by the Union, in the elaboration of its policies, as guiding principles but without the legal effectiveness of a rule ${ }^{1}$.

The evolution of social rights in the E.U. has undergone a long and tortuous journey. With the establishment of the C.E.E. in 1957, the art. 117 established that social policies were the exclusive responsibility of the Member States and with art. 118 attributed to the Commission only a faculty limited to the coordination of the collaboration between them in the field of social rights.

With the Treaty of Paris of 1951, with the establishment of the C.E.C.A. (European Community of Coal and Steel) was established by the Court of Justice which with the Treaty of Rome of 1957 became the Court of Justice of the European Communities (C.J.C.E.).

This body, with its own jurisprudence was the first step of the E.U. to contribute and consolidate social rights in the European regulatory framework, making these general principles suitable for being part of the European legal system.

With the Treaty of Rome, subsequently amended by the 1987 Single European Act, some Community competences regarding social rights are expressly stated. Among others, the principles for free movement of workers and equal pay for men and women are declared.

Protection of social rights in the EU it was ratified in 1989 at the European Council in Strasbourg, with the adoption of the Community Charter of the Fundamental Social Rights of Workers, which in any case left the Member States with the power to implement them. It was therefore a pragmatic act that dictated its principles.

The skills of the social sector are expanded with the introduction of the Maastricht Treaty in 1992, where the pursuit of employment and social protection, the improvement of the quality of life, economic-social cohesion and solidarity among member states are enshrined. .

In 1997 the Amsterdam Treaty constitutionally recognizes social rights as a guiding criterion of the social policy of the EU.

In 2000 the Charter of Fundamental Rights of the EU is voted by the European Council of Nice, a document that accurately lists all the rights of which citizens and residents of the Union are beneficiaries.

\footnotetext{
${ }^{1}$ Gradilone, S.; L'attenzione in merito alla tutela dei diritti umani e delle libertà fondamentali nell'UnioneEuropea. 2017. Recovered in April 2018 from the site: https://www.balcanicaucaso.org/aree/Europa/Unione-europea-una-questione-di-diritti-177090.
}

e-Revista Internacional de la Protección Social, ISNN 2445-3269. 2018, Vol. III, N ${ }^{\circ} 1$ 
But the important turning point is in 2007, when with the adoption of the Treaty of Lisbon, the Charter ceases to be a mere declaration of principles, and assumes binding legal value.

The latter expresses the freedoms and rights in which the Union recognizes its legal heritage and is relevant to dignity, freedom, equality, solidarity, citizenship and justice, whose respect is already protected by the principles constitutional issues common to member states and the European Convention for the Protection of Human Rights and Fundamental Freedoms ${ }^{2}$.

Another step was taken on 17 November 2017, on the occasion of the European social summit in Gothenburg, when the European Pillar of Social Rights was officially proclaimed, declared in the year 2015 by President Juncker in his speech on the State of Union.

According to the European Union, the Pillar takes into account the transformations taking place in the world of employment and will be the guide for a renewed process of convergence towards better working and living conditions among the Member States, through a fair and well-functioning labor market and welfare systems ${ }^{3}$.

The European Pillar aims to make citizens' rights more effective and is based on 20 key principles, structured in three categories such as equal opportunities and access to the labor market, fair working conditions and social protection and inclusion.

It is supported by a scoreboard of key indicators and serves as a reference to monitor "social progress", which means the ability to foster and support wellbeing and opportunities, creating conditions that allow people to fully develop their potential and meet their basic needs .; this monitoring tool would allow the assessment of the employment and social results achieved by the Member States with the E.U. and the euro area average and in some cases also with those of other international actors and to carry out a comparative analysis. All assessments would be discussed with the relevant Council committees, with a view to inclusion in the annual report on employment, published each autumn within the framework of the European Semesters.

The range of themes dealt with is very broad in terms of the articulation and social complexity, but also because of the diversity of the conditions in which the citizens of the E.U. The principles give the guidelines to face new developments in the world of work and in society in order to achieve a competitive social market economy that aims at full employment and social progress.

\footnotetext{
${ }^{2}$ The European Convention for the Protection of Human Rights and Fundamental Freedoms or the ECHR is an international convention drafted and adopted within the Council of Europe, signed in Rome on 4 November 1950 and supplemented and amended by 14 additional protocols. The ECHR is considered the central text on the protection of fundamental human rights because it is the only one with a permanent judicial mechanism that allows each individual to request protection of the rights guaranteed there, through the appeal to the European Court of Human Rights of the man, based in Strasbourg.

${ }^{3}$ European Pillar of Social Rights: The Pillar has been presented in two legal forms of identical content: a Commission recommendation, which takes effect immediately, and a proposal for a joint proclamation of Parliament, Council and Commission. On this basis, the Commission will launch discussions with the European Parliament and the Council to ensure the Pillar broad political support and high-level approval.
}

e-Revista Internacional de la Protección Social, ISNN 2445-3269. 2018, Vol. III, No 1 http://dx.doi.org/10.12795/e-RIPS.2018.i02.13. Páginas: 230-244 
These are mostly sectors of political competence of the Member States and of national scope. But the European Union is entrusted with the task of defining the general framework of these rights and the direction to be taken to make them effective. It also has a part of its own competencies to act in order to implement the principles enunciated.

The idea underlying the Pillar is to create a framework with specific indicators to promote social convergence among the Member States of the Union and to intervene, through the creation of new tools, where integration within of the Economic and Monetary Union had created negative conflicts.

The proclamation of the European Pillar is a clear turning point in the European discourse on social rights, an opportunity for change that, if effectively exploited, could trigger positive dynamics at the unexpected moment. It is the first and essential step for the launch of a more social Europe, even if its implementation requires the action not only of the European institutions, but also of the governments, the social partners of the Member States and their respective federal and regional administrations ${ }^{4}$.

The aim of the pillar is to give substance to the provisions of the Charter of Fundamental Rights of the European Union, considering it as strategically important as to require an original and non-ordinary procedure.

The Charter improves the "legal corpus" and guarantees certain personal, civil, political, economic and social rights of citizens and residents of the Union, with particular reference to the principle of non-discrimination in its various manifestations.

For the implementation of E.P.S.R. the Commission indicates the adoption of an interinstitutional agreement by the Parliament and the Council which would constitute a solemn act aimed at enhancing, through the shared commitment of the various European institutions, its crucial nature.

However, there remains the risk of inconsistency of this initiative as well as the inability to produce concrete effects in the short to medium term, actually ending with the igniting hope then disregarded, since the legislative process should be supported by all Member States.

The contents of the Pillar are linked to employment and, as they are formulated, are likely to result in social rights understood as collective rights, conferred on the basis of the state of employment; social rights, on the other hand, are individual rights applicable to all, regardless of job position.

The Pillar is a tool to recognize and address the changes taking place at the social, demographic, economic and professional levels. It intends to create the conditions and accompany the path of the EU towards a confluence in this area, so that every citizen of the Union has equal rights, protections and opportunities. After years of efforts aimed at

\footnotetext{
${ }^{4}$ Menéndez-Valdés J.; 2017. E.U. Social Pillar: “A Potential New Start For Europe. Social Europe”. London, Great Britan. 2017. Recovered in April 2018 from the site: https://www.socialeurope.eu/50326-
}

e-Revista Internacional de la Protección Social, ISNN 2445-3269. 2018, Vol. III, N 1 
integrating the single market and the currency, it wants to focus attention on citizens and on social reality, hoping for a closer coordination of social and labor policies also through enhanced cooperation between member countries with the extension of more protections.

\section{INCIDENDE OF THE PILLAR IN THE SOCIAL POLICIES OF THE EUROPEAN UNION}

The European Pillar presents some critical issues concerning primarily its legal nature which, as an act of proclamation, is not suitable to promote an effective politicalconstitutional refoundation of social rights, considering them as activation tools on the labor market, to the detriment of the protective dimension - redistributive.

At the Pillar, the system of the "open method of coordination" is applied, where the individual states are oriented towards achieving different common objectives but following different paths, with the monitoring of the Union.

This is a method that provides for a voluntary system of political cooperation and confrontation, of the common objectives to be achieved and presumes the collaboration of civil society and social partners.

A limit represented by this method is the lack of integration of social policy with other Community policies, especially with monetary policy, to date the only one reached, in which the EU can exercise control and apply sanctions to all Member States; in the field of social policies, however, it does not yet have defined tools for the standardization and application of the same, therefore it can not perform a control function but only limit itself to observation.

The political structures of the E.U. they consider economic and monetary union as a social project having as its purpose the creation of conditions favourable to a strong and shared growth for all citizens belonging to the Union. But in reality, the costs of social policies and monetary restraints continue to cause a situation of social inequality in the Member States, since the less virtuous states have difficulty extending the benefits to the entire population.

It is impossible to implement a Community social policy which can be applied equally to all Member States, which are obliged to respect monetary parameters, especially if not all of them have equal economic conditions. Although the European Pillar of Social Rights should be a framework for certain social rights to be not only sanctioned but locally made viable, it is not accompanied by any directive that allows states in economic distress to derogate from the money pacts.

Giving value to the Pillar is one of the political priorities outlined by the E.U. to build a more inclusive and fairer Union, through the fight against poverty, the reconstruction of human capital, the ability to recover from asymmetric shocks and the importance of the social economy. These objectives will be pursued in connection with and in the framework of the mid-term review of the Europe 2020 Strategy, which should lead to a more inclusive decision-making process, based on the involvement of the social

e-Revista Internacional de la Protección Social, ISNN 2445-3269. 2018, Vol. III, No 1 http://dx.doi.org/10.12795/e-RIPS.2018.i02.13. Páginas: 230-244

Página 237 
partners, on the coordination of economic, employment and social policies to be further strengthened in accordance with existing procedures and in full respect of national competences.

Moreover, considering the massive immigration flow in the E.U. area, it is not reasonable to think about implementing social rights without considering the economic and social contribution made by foreign immigrants from outside the E.U.

In fact, while the Charter envisaged the preparation of an immigration project that would include admission procedures, underlining the adoption of measures to integrate third-country nationals, hoping for a common European framework with fundamental principles $^{5}$, this project in the Pillar is not reflected, confirming that the E.U. since it does not have exclusive competence in the social field, it fails to make its rights legally effective. Moreover, this proves to be lacking because it shows a disparity based on the administrative condition of the non-E.U. foreigner, as at national level "the immigration rules and the treatment of foreigners preclude access to equal rights, even fundamental rights"6.

Although the right to migration has been recognized, barriers continue to persist that each member state of the E.U. has raised the exercise of the same right.

In fact, from the point of view of irregular immigration control, States implement a progressive restriction of the right to emigrate. Immigration continues to remain a question that states want to reserve for their political action and national sovereignty, which is the limit beyond which the E.U. he cannot continue. If the foreign immigrant from non-EU countries enjoys lower rights by law and is subject to more burdensome duties than EU citizens, there will continue to be a serious problem of discrimination to be remedied through the reform of the legal provisions, or through the jurisdiction constitutional.

Although with the proclamation of Göteborg an attempt was made to provide a shared framework at supranational level, a guide should be encouraged leading to a concrete implementation of the project involving the Governments of the Member States. To implement the Pillar it is necessary to design concrete measures and instruments that support it; if this were not implemented, the European institution would once again be rejected.

The Pillar does not contain explicit references to non-E.U. foreign citizens, and indeed the Italian Government ${ }^{7}$ on December 22, 2017 sent the European Commission an official reply from Italy to the consultation. In his observation, the attainment of the

\footnotetext{
${ }^{5}$ Chiaromonte, W.; Lavoro e diritti sociali degli stanieri. Torino, Italia. Giappicchelli Editore 2013

${ }^{6}$ Favilli, G.; I diritti dell'immigrato non regolarmente soggiornante (cit. pag. 295). L'Aquila, Italia: Edition Il Sirente. 2008

${ }^{7}$ Italian Government: in the Italian legal order the Government exercises executive power. According to art. 92 c. 1 of the Constitution distinguishes three many bodies: the president of the Council of Ministers, prime minister, ministers and the Council of Ministers. The formation of the Government is disciplined briefly by art. 92 , c. 2,93 and 94 of the Constitution and constitutional rules consolidated him in time. The government depends on the trust of both the branches of parliament and has in its power the possibility of issuing decrees in case of emergency.
}

e-Revista Internacional de la Protección Social, ISNN 2445-3269. 2018, Vol. III, No 1

http://dx.doi.org/10.12795/e-RIPS.2018.i02.13. Páginas: 230-244

Página 238 
objectives described in the European Pillar can be achieved both through the expansion of adequate social policies at national level, and through the participatory implementation of instruments and actions at the EU.

The integration of non-EU foreign immigrant citizens requires an integrated and systematic approach that looks at all dimensions of life, with particular attention to school, work, health and social security ${ }^{8}$.

Regulatory action is not envisaged only by the European institutions, but a set of actions carried out by the competent bodies in compliance with the principles of subsidiarity and proportionality, thus ensuring that implementation can respect national and local differences, so marked at internal to the E.U. On the other hand, it is not a matter of introducing a completely new legislation, but of integrating what already exists in the Community acquis ${ }^{9}$ and of making it effective or extending its protections where necessary.

Another objective of the Pillar is the balancing of economic imbalances within the Economic and Monetary Union ${ }^{10}$, exasperated during the 2008 financial crisis, which would be implemented through Labor Policies, or in responding to differences that have arisen between the countries participating in the single currency, due to the imposition of common rules.

The Maastricht parameters represent a different economic development model among the northern countries of the E.U. more favoured by the criteria of the E.M.U. and the most disadvantaged in the South, due to the budgetary imbalances they have to face, which grow worse when they face, as a single state, humanitarian emergencies.

\footnotetext{
${ }^{8}$ Governo Italiano; 2017. Recovered in April 2018 from the site: http://www.governo.it/approfondimenti/2017/12/pilastro-europeo-dei-diritti-sociali-alla-camera-lesamedel-testo/.

${ }^{9}$ The Schengen acquis is a set of rules and regulations, integrated into the right to the European Union, aimed at promoting the free movement of citizens within the so-called Schengen Area, regulating relations between the States that have endorsed the Schengen Convention. The complex of rules, also called Schengen agreements, takes the name of the city of Schengen, in Luxembourg. The Schengen acquis includes the Schengen agreement signed on June 14, 1985 by the Benelux States, Germany and France, the Schengen Agreement, signed on June 19, 1990, the accession agreements to the Convention implementing the Schengen agreement on behalf of Italy, Spain, Portugal, Greece, Austria, Denmark, Finland and Sweden.

The new E.U. member countries of 2004 and 2007 are obliged to enter the Schengen area, but for four of them the agreement has not yet entered into force: the other E.U. countries have achieved a transitional period before directing the free movement of people, in addition the new member countries have to equip themselves with all the appropriate infrastructures to implement the Schengen information system.

${ }^{10}$ The economic and monetary union, E.M.U., of the European Union has been sanctioned with the Maastricht Treaty, which, for three subsequent phases, concluded a long process of diplomacy whose result is most notably represented by the coinage and adoption of a single European currency , the euro, replacing the corresponding national currencies of the 19 countries, Austria, Belgium, Cyprus, Estonia, Finland, France, Germany, Greece, Ireland, Italy, Latvia, Lithuania, Luxembourg, Malta, the Netherlands, Portugal, Slovakia, Slovenia and Spain, with a common monetary policy under the control of the European Central Bank (E.C.B.), giving life to the so-called euro zone. The economic policies of each state are coordinated among them through the union, therefore there are still prerogatives of the States that accept a limitation imposed by the Treaty on the functioning of the European Union, T.F.E.U.
}

e-Revista Internacional de la Protección Social, ISNN 2445-3269. 2018, Vol. III, N ${ }^{\circ}$

http://dx.doi.org/10.12795/e-RIPS.2018.i02.13. Páginas: 230-244

Página 239 


\section{THE COMPLEXITY OF NATIONAL WELFARE SYSTEMS IN THE IMPLEMENTATION OF THE EUROPEAN PILLAR}

In implementing the Pillar, there is a political problem, that is the unavailability to change the European rules by those countries that, to date, have benefited most.

The Stability and Growth Pact (S.G.P.) is an agreement signed in 1997 by the member countries of the European Union, linked to the control of public budget policies, with the aim of preserving the membership requirements of the Economic and Monetary Union of the European Union (Eurozone) consolidating the path of monetary integration started in 1992 with the Treaty of Maastricht. Compliance with the S.G.P. does not allow governments any margin for its budgetary policy, and therefore the possible application of the Pillar, which would structurally change Welfare, without changing the economic policy of the $\mathrm{EU}^{11}$.

Moreover, the choices of the Union in the field of economic governance, with effects on the decisions of the individual member states on public social expenditure, must be considered in relation to the absence of competences in the social field of the E.U., referring to direct competences. , which, however, will hardly be granted to the Union in the future, because to do so, the unanimity of the member states would be needed, which at the moment is difficult to achieve and continues to represent one of the great limits of the Union.

In order to make the Pillar effective, the objective of the EU is to be able to assess the compliance of the legal systems of the member states, with respect to the provisions of the text, bearing in mind that the Commission's recommendations are not legally binding and have no legal effect, they only serve as declarations of principle that should inspire future choices policies of the EU States.

The publication of the recommendation is not the final stage of work on the Social Pillar. With its approval, the Commission took a position, thus opening a further phase of discussion with the Council and the European Parliament with a view to the adoption of a shared text, as well as continuing the dialogue with civil society on the guidelines adopted.

Meanwhile, the Commission has already started the process of approving some provisions on the balance between professional and family life, information to workers and access to social protection.

This approach implies a clear convergence of visions and interventions by all the subjects involved and constitutes an important bet for the future of European construction, since the ability to collaborate is at stake.

The principles identified in the pillar are intended to accompany and guide the transformation of work following globalization, the digital revolution and the

\footnotetext{
${ }^{11}$ Corti, F. and Vesan, P.; Il pilastro europeo dei diritti sociali. 2018. Recovered in April 2018 from the site of the magazine: http://www.secondowelfare.it/primo-welfare/innovazione-sociale/il-pilastroeuropeo-dei-diritti-sociali-
}

e-Revista Internacional de la Protección Social, ISNN 2445-3269. 2018, Vol. III, No 1

http://dx.doi.org/10.12795/e-RIPS.2018.i02.13. Páginas: 230-244

Página 240 
affirmation of new organizational models. The challenges of the demographic decline and of the social changes in progress are not forgotten.

Economic and social progress are interrelated and the expansion of a European Pillar of Social Rights must be part of an application to achieve a more inclusive and sustainable growth model, making Europe's competitiveness better and presenting it more favourable. investment, job creation, consolidation of the social union without abandoning the immigration element, which today is an integral part of the E.U., and whose economic and social aspects continue to be neglected ${ }^{12}$.

The projects aimed at implementing the development model will engage both the EU that the Member States with the single market, financial devices and policy instruments. They will be used for the elimination of obstacles. As an immediate priority, the Commission has specified the measures to be chosen by indicating a reliable exit strategy, reforming the financial system, ensuring the re-establishment of the budget for long-term growth and strengthening the organization with the Economic and Monetary Union. To achieve concrete results, a stronger economic governance will be needed to harmonize priorities, main objectives and reports on individual countries that will support Member States to plan their strategies to restore the sustainability of growth and public finances. At the level of the E.U. Integrated directions covering the priorities and targets of the Union will be accepted, while specific recommendations will be addressed to the Member States ${ }^{13}$.

The European Pillar of Social Rights aims to serve as a guide to delivering effective social and employment outcomes in response to current and future challenges so as to meet the essential needs of the population and ensure better implementation and enforcement of social rights.

The EU pushes for the cooperation between the two components of the European representative democracy, as declined in the art. $10 \mathrm{TUE}^{14}$.

Calls for the revival of a solidarity policy in Europe through the Pillar of Social Rights, which is expressly seen as an integral part of the convergence process within the Economic and Monetary Union and which, while not intended to expand the Union's competences, tends to enhance those already expressly recognized and to strengthen the action of member states in ensuring greater attention to this side of the integration process $^{15}$.

\footnotetext{
${ }^{12}$ Sabbattini, G.; La Governance unitaria dell'area euro, pilastro della crescita inclusiva dell'Unione Europea. Magazine Manifesto Sardo, nr. 23/2017.

${ }^{13}$ Pierini, M.; Crisi e ripresa economica in Europa. 2014. Recovered in April 2018 from the site of the magazine: http://www.europadirectmarche.it/notiziario/2014

14 The Treaty of Maastricht, or Treaty of the European Union (T.U.), is a treaty that was signed on February 7, 1992 in Maastricht in the Netherlands, of the twelve member countries of the then European Community, today the European Union, which it establishes the political rules and the economic and social parameters necessary for the entry of the various acceding States in said Union. It has entered into force on November 1, 1993.

${ }^{15}$ Saitto, F.; Risocializzare 1'Europa. La dimensione sociale europea tra economia e integrazione sovranazionale. 2018. Recovered in April 2018 from the site of the magazine:
}

e-Revista Internacional de la Protección Social, ISNN 2445-3269. 2018, Vol. III, No 1 http://dx.doi.org/10.12795/e-RIPS.2018.i02.13. Páginas: 230-244 
The commitment on the front of the Pillar of social rights will have to take into account the importance that in this context continue to play the sovereign choices in welfaristic matters of the individual member states.

This political commitment structurally links democracy and solidarity in the establishment of a process of convergence, which must lead to rebuilding trust in a European Union that is really capable of responding to the social demands that the current phase poses.

This in order to promote a new concept that takes into account the historical context in which the States are called to operate, thus proving to relaunch the process of European integration.

Furthermore, the EU it should take into account that currently there is no single social model applied by all Member States, but that these models are diversified within them according to the historical paths of the States.

In the EU four theoretical models of welfare are identified, the social-democratic model of the countries of northern Europe, the liberal model of the Anglo-Saxon states, the corporate model of the continental states and the Mediterranean model of the southern states. They are derived from the different historical and economic paths of the States and differ mainly due to the type of service provided and the expected funding.

The North-European model is characterized by the principle of universalism, its objective is the protection of all, is based on the state of need of every individual and socially recognizes the equality of citizens. Unlike, the liberal model, it is aimed at reducing poverty, the interventions are targeted at specific risk groups and the labor market is the main means of depreciating poverty.

The corporate model is oriented towards the protection of workers and their families when their capacity to provide for the needs of the components becomes insufficient. State interventions reduce dependence on the labor market; in the Mediterranean welfare it is the family that has to ensure the satisfaction of the needs of its members and the State plays a marginal role, by not providing any kind of economic aid but only by providing services. This determines a process of regionalization of social policies that give rise to a gap between the richest parts of a country with the most disadvantaged, creating situations of social discrimination.

By analyzing the social systems, it is observed that the North-European and continental ones reach objectives in the average indicated by the E.U. While the Anglo-Saxon system hardly reaches the average level of European satisfaction, the Mediterranean one according to the limited benefits before retirement, does not reach, for some countries including Italy, the minimum social threshold of the $\mathrm{EU}^{16}$.

http://www.diritticomparati.it/rivista/risocializzare-leuropa-la-dimensione-sociale-europea-tra-economiadi-mercato-e-integrazione-sovranazionale/

${ }^{16}$ Borger, V. (2013). How the Debt Crisis Exposes the Development of Solidarity in the Euro Area, in European Constitutional Law Review. (pag. 9: 7-36, 74). Articolo pubblicato sulla rivista Cambridge University Press (nr. 9) il 19.04.2013.

e-Revista Internacional de la Protección Social, ISNN 2445-3269. 2018, Vol. III, No 1 http://dx.doi.org/10.12795/e-RIPS.2018.i02.13. Páginas: 230-244

Página 242 
The obvious distortion is that the E.U. should pay more attention to capital and not just to work, as implemented until now, and this policy over time, in the absence of economic corrections, will increase the social gap between E.U. states, despite the good intention of paying attention to rights, lastly, the proclamation of the E.P.S.R.

The Pillar, as well as the integration policy adopted by the E.U., shows its limits considering the work as a de facto integration. It is assessed as the point of arrival of the integrative path of the immigrant foreigner, who should create his own social life around it.

But this is only an economic integration, which does not bring any social benefit, relegating foreign immigrants from outside the Community on the margins of society, as happened in France, during the riots in the Banlieues.

It is desirable that the EU addresses the Pillar in the direction of the evolution of a model of integration that includes some cornerstones applicable throughout the Union, such as the language of the host country, culture, education and the right to health, which until today are regulated in a generic way.

With the approach that the Union wants to give to the Pillar, making the role of work central, a context is created in which the non-EU foreign immigrant has to approach the civil society. Instead, the latter has to change its contact system, heading towards the reality of foreign immigration to obtain mutual benefits.

To do this, it is necessary to keep the attention on the Pillar and its Proclamation high, that the social partners, political parties and the public are mobilized to remember that the signing of the inter-institutional Proclamation is a strategic political commitment.

Of course, it is not a legally binding act and its signature does not automatically imply that the principles and rights contained therein are guaranteed, that is why political will be decisive for implementing concrete legislative initiatives, making it more difficult for governments to compromise their commitment to Gothenburg.

\section{CONCLUSIONS}

The objective of the pillar is to implement integration through labor policies because, according to the European institution, it makes social relations possible. But if it were applied in today's structure would only result in economic integration, and would not offer any social advantage, relegating non-E.U. foreign migrants to the margins of society.

The social partners, political parties and the public must consider the implementation of the pillar as a fundamental strategic political commitment but, given its non-legally binding nature, it does not automatically imply that the principles and rights contained therein are guaranteed, considered the significant costs to be met for the implementation of social policies and the financial rigor imposed by the monetary policy of the Union.

e-Revista Internacional de la Protección Social, ISNN 2445-3269. 2018, Vol. III, No 1 
Because of the rigidity of the E.M.I., in order to reduce the economic and social imbalances between the Member States, the E.U. it focused on workers' mobility, but the lack of a political and fiscal union has shown that all acts, including the E.P.S.R., are addressed to heterogeneous political systems and are not finalized with transnational solidarity, making a system in fact impractical. of common welfare. Proof of this is the 2013 invitation, in the midst of the economic crisis, of Germany and other Northern European states to the Community institutions in order to review the rules on the mobility of citizens. and non-E.U. citizens in a restrictive sense, aimed at avoiding the welfare of the host country. Although contrary to the principles of free movement, this invitation inspired in 2015 the proposal of the Labor Mobility Package, which aimed at introducing stringent criteria for access to the welfare of the host country, but, to date, has not led to any directive in this sense.

Therefore, the EU, which has based its idea of integration and sociality on the efficiency of the labor market, to increase competitiveness and heal imbalances, with the Pillar would like to guarantee to all citizens, in the community and, residuals to nonE.U. immigrants, conditions of parity with the citizens of the host country. But just as monetary policy, based on labor mobility, shows today an economically divided Europe, social policies, reasonably, if realized with the current Pillar text, in the medium term, will show the limits and inability of integrate and merge.

The perception is that the Member States with advanced economies consider themselves surrounded by economic immigrants and this causes them to touch down their social system with the introduction of corrections linked to the type and duration of employment contracts ${ }^{17}$.

In order to guarantee equal social rights, the E.U. it must give impetus to investment policies in the less efficient areas, reversing the trend of labor mobility, opening up its policy to non-E.U. immigrants who would find a full space in the welfare state and represent economic and cultural wealth.

The current breakdown of the economic policies that divide Europe can only be remedied by the establishment of an institution that has a political personality capable of aggregating and changing monetary policy, revising the rigidity of the Fiscal Compact, which must be made more flexible, because today it does not take into account the economic and social variables that Europe is experiencing.

Together with the establishment of a common European state, it is necessary to support a social and integration policy managed directly by the central entity, which is able to aggregate by introducing transnational solidarity and which would certainly encourage the growth of this inclusive political model.

\footnotetext{
${ }^{17}$ Direttiva nr. 2004/38. (2004). Art. 7, par. 1, lett. b.; art. 12, co. 2; art. 13 co. 2 e art. 14 co. 1, making the freedom of movement and residence of inactive Community citizens conditional on not constituting an 'excessive burden' for the social assistance system of the host Member State
}

e-Revista Internacional de la Protección Social, ISNN 2445-3269. 2018, Vol. III, No 1 